\title{
Resilience of Zostera noltii to burial or erosion disturbances
}

\author{
Qiuying Han ${ }^{1,2, *}$, Tjeerd J. Bouma ${ }^{2}$, Fernando G. Brun ${ }^{3}$, Wouter Suykerbuyk ${ }^{2,4}$, \\ Marieke M. van Katwijk ${ }^{4}$
}

\author{
${ }^{1}$ Key Laboratory of Coastal Zone Environmental Processes, Yantai Institute of Coastal Zone Research (YIC), \\ Chinese Academy of Sciences (CAS); Shandong Provincial Key Laboratory of Coastal Zone Environmental Processes, \\ YICCAS, Yantai Shandong 264003, PR China \\ ${ }^{2}$ Centre for Estuarine and Marine Ecology, Netherlands Institute of Ecology (NIOO-KNAW), PO Box 140, \\ 4400 AC Yerseke, The Netherlands \\ ${ }^{3}$ Department of Biology, Faculty of Marine and Environmental Sciences, University of Cádiz, 11510 Puerto Real, Cádiz, Spain \\ ${ }^{4}$ Radboud University Nijmegen, Institute for Water and Wetland Research, Department of Environmental Science, \\ Heyendaalseweg 135, 6525 AJ Nijmegen, The Netherlands
}

\begin{abstract}
Dynamic environments like seagrass habitats are characterised by continuous local erosion and burial processes, which may induce seagrass decline if disturbances become too intense or frequent. We aim to quantify for Zostera noltii the resilience of both the edge of a meadow and individual propagules to local-scale burial and erosion events. In a set of mesocosm and in situ manipulation experiments, we varied the frequency (sudden vs. continuous rate) and intensity (different levels; $-6 \mathrm{~cm}$ erosion to $6 \mathrm{~cm}$ burial) of sediment dynamics. Our results showed that the intensity of the disturbance event $(-6$ up to $6 \mathrm{~cm}$ ) was negatively correlated with plant survival. Burial frequency also had a significant effect on plant survival, with sudden events having a stronger negative impact than continuous ones. Both experiments, on individual propagules and attached rhizomes at meadow edges, demonstrated a rapid acclimatization of seagrass plants to sediment dynamics within certain levels of disturbance (-6 up to $6 \mathrm{~cm})$. After erosion or burial, all surviving plants in the field and mesocosm experiments were able to relocate their rhizomes to the preferential depth (from 0.3 to $0.8 \mathrm{~cm}$ ), which was the depth at which the rhizomes of undisturbed plants were most frequently found in the field. In situ manipulation experiments showed that at the edge of the meadow, $Z$. noltii invaded experimentally created hollows more easily than hills. Overall, our results demonstrate that $Z$. noltii meadows can rapidly recover by clonal growth after modest sediment disturbance, thereby contributing to the current understanding of seagrass recovery mechanisms following disturbances (e.g. sediment dynamics).
\end{abstract}

KEY WORDS: Recovery · Rhizome growth · Burial · Erosion · Disturbances · Zostera noltii • Seagrass $\cdot$ Resilience

Resale or republication not permitted without written consent of the publisher

\section{INTRODUCTION}

Seagrasses occur widely in coastal zones throughout the world, where they provide critical ecosystem functions and services (Short \& Wyllie-Echeverria 1996, Orth et al. 2006). The accelerating widespread loss of seagrasses has multiple causes, physical dis- turbance and eutrophication being the most important ones (Orth et al. 2006, Waycott et al. 2009). Physical disturbances may arise from large-scale processes like coastal construction activities, dredging, sediment deposition, anthropogenic or climatically driven hydrological alterations (e.g. Cunha et al. 2005, Hammerstrom et al. 2006, Dolch \& Reise 
2010), but may also occur at a local scale, due to bioturbation, grazing, boat anchoring and manual collection of fauna (e.g. Bolam \& Fernandes 2002, Cabaço et al. 2005, Vonk et al. 2008). It is also likely that large-scale disturbances may aggravate effects of local disturbances. The resilience of seagrass meadows to local disturbances through rapid acclimation and sufficient recovery potential of plants are thus vital for their long-term survival.

Sediment dynamics create important and widespread disturbances to seagrasses, as extreme burial and erosion events can be detrimental (Cabaço et al. 2008). Due to different resource allocation strategies and life-history characteristics, seagrass species may differ in tolerance to burial and erosion events (Preen et al. 1995, Duarte et al. 1997, Terrados et al. 1998, Cabaço \& Santos 2007). Mortality of large seagrasses such as Posidonia oceanica was significantly correlated to the burial level, and even moderate burial levels of $5 \mathrm{~cm}$ induced significant shoot mortality (Manzanera et al. 1998). Mills \& Fonseca (2003) showed that increasing burial of Zostera marina significantly increased mortality and decreased productivity. Marbà \& Duarte (1994) demonstrated that Cymodocea nodosa seedlings tolerated burial of $<7 \mathrm{~cm}$, while moderate burial stimulated the growth of surviving seedlings. In the case of the small-sized seagrass $Z$. noltii, both erosion $(-2 \mathrm{~cm})$ and burial $(2 \mathrm{~cm})$ decreased shoot density in natural meadows, while the burial threshold for the shoot dying out was found to be between 4 and $8 \mathrm{~cm}$ (Cabaço \& Santos 2007). Moreover, under laboratory experimental conditions, individual shoots of $Z$. noltii did not survive $>2$ wk under complete burial (Cabaço \& Santos 2007).

Nowadays, erosion has become an important process in many coastal ecosystems, such as the Wadden Sea (NW Europe) (van Katwijk et al. 2000, Polte et al. 2005), Cádiz Bay (SW Spain) (Brun et al. 2005) or the Thames estuary (SE England) (Hughes \& Paramor 2004). However, compared to sediment burial, few studies have directly assessed the effects of erosion on seagrass performance, even when erosion has been demonstrated to promote seagrass loss (Marbà \& Duarte 1994, Short \& Neckles 1999, Cruz-Palacios \& van Tussenbroek 2005, Cabaço \& Santos 2007). Among the studied species, Thalassia testudinum seemed to have a relatively high tolerance to erosion when compared to Cymodocea nodosa, Syringodium filiforme and Zostera noltii, as neither a response to shoot density nor to the length of the rhizome was observed (Cabaço et al. 2008). Considering the small size, the low aboveground biomass and the thin rhi- zomes, one may expect $Z$. noltii to be highly sensitive to sediment dynamics. Cabaço \& Santos (2007) showed that $Z$. noltii attempted to relocate the leafproducing meristems closer to the sediment surface or in search of new sediment avoiding the eroded area. As a small species, Z. noltii may have a pronounced capacity of occupying empty gaps, coupled with large changes in plant morphometry and photosynthetic parameters (Peralta et al. 2005).

Currently, seagrass beds (mainly constituted by Zostera noltii) in the Wadden Sea (NW Europe) and eastern Scheldt (SW Netherlands) are limited to the upper part of the tidal flat, close to the high tide line (Polte et al. 2005). These meadows are typically surrounded by many elevations and depressions (Fig. 1A), causing local erosion or burial of apical shoots at the edges of the meadow (Fig. 1B,C) rather than affecting the whole meadow. Likewise, these elevations and depressions are likely to also affect recently established seagrass propagules. Moreover, the recovery of disturbed seagrass beds is often strongly dependent on the horizontal vegetative growth from apical (i.e. runner) shoots located at the edge of the meadows and on the establishment of new patches from detached propagules (Duarte 1995, Neckles et al. 2005, Boström et al. 2006, Brun et al. 2006, Zipperle et al. 2009). For this reason it is highly important to study the response to local sediment dynamics and the mechanisms underlying such a response, for the plants located at the edge of a meadow that are responsible for the expansion of the meadow and the propagules that can initiate the colonization of new areas. Nevertheless, previous studies have mainly focused on the sediment dynamics of the whole meadow (Cabaço et al. 2008), neglecting these more local-scaled processes.

In the present study, our main objective was to quantify the resilience (acclimation and recovery) of seagrasses to local sediment dynamics. To achieve this, we assessed the resilience of both Zostera noltii propagules and attached rhizomes at the edge of a meadow to contrasting sediment scenarios of local erosion and burial using a set of mesocosm and manipulative field experiments. Sediment scenarios were applied as: (1) sudden burial of individual $Z$. noltii propagules at contrasting depths (mesocosm), (2) continuous burial and erosion of individual $Z$. noltii propagules (mesocosm), (3) local attached rhizome burial or erosion at the edges of a $Z$. noltii meadow (field) and (4) re-colonization of bare areas within a meadow that had contrasting elevations and depressions relative to the surrounding meadow (field). We assessed the resilience of seagrasses to 

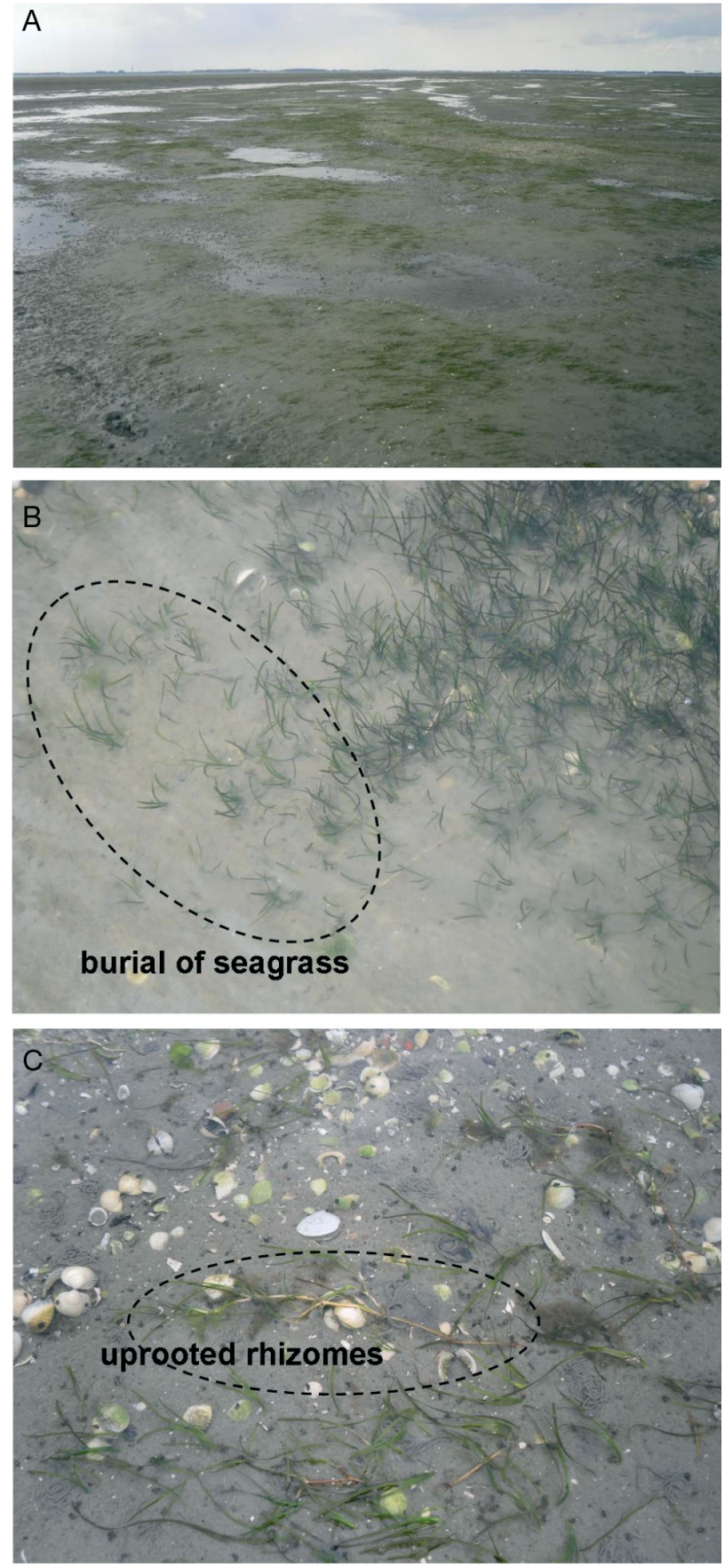

Fig. 1. Typical sediment topography around seagrass meadows in the eastern Scheldt estuary (SW Netherlands). On the large scale, ridges and runnels (A) can be observed, which may cause small-scale burial (B) or uprooting (C) of rhizomes

local sediment dynamics (burial and erosion) by measuring the depth of each newly formed rhizome, as this provides a measure of how fast plants can adapt to burial and erosion events, by returning its rhizomes to the depth where they frequently occur. In addition, we also measured a set of parameters to describe the plant response to disturbance, like plant survival (e.g. see Cabaço \& Santos 2007), rhizome elongation rate (e.g. Olesen et al. 2004), shoot number (e.g. Rollon et al. 1999) and biomass (e.g. Schanz \& Asmus 2003).

\section{MATERIALS AND METHODS}

\section{Mesocosm experiments}

Effect of sudden burial on individual propagules

To assess the effect of sudden burial on the survival, elongation rate and rhizome depth of propagules, Zostera noltii propagules (1 apical shoot plus the first lateral shoot, and respective internodes) were buried in PVC cylinders $(12 \mathrm{~cm}$ diameter and height). Cylinders were filled with muddy sand sediment (grain size [mean $\pm \mathrm{SD}$ ] was $118.83 \pm 1.19 \mu \mathrm{m}$, organic content was $0.25 \%$ ). Sediment cover of the propagules was $0.5,1,1.5,2,2.5,3,4$ or $6 \mathrm{~cm}$. Only at the burial depth of $6 \mathrm{~cm}$ were shoots completely covered (as shoot length was $5.22 \pm 1.16 \mathrm{~cm}$, mean $\pm \mathrm{SD}$, $\mathrm{n}=576)$.

Each treatment had 12 replicates. The PVC cylinders were kept submerged in aerated and filtrated seawater (31 psu). The seawater was slowly flowing, and was changed twice every week. During the experiment, the daily average integrated photoirradiance at the surface of the mesocosm was $22 \mathrm{~mol}$ photons $\mathrm{m}^{-2} \mathrm{~d}^{-1}$ with a photoperiod of $18 \mathrm{~h}$ light: $6 \mathrm{~h}$ dark, which was similar to the optimum daily light dose for Zostera noltii growth (Peralta et al. 2002). Temperature was kept constant at $19^{\circ} \mathrm{C}$. After $4 \mathrm{wk}$, we counted the number of surviving shoots in each cylinder and surviving plants in each treatment, and measured the burial depth and length of each internode (including the new rhizomes produced).

The depth at which rhizomes were buried was initially measured using 2 different methods. (1) We measured rhizome depth by using a ruler with a millimetre scale, pushing it gently into the sediment and then stopping when rhizomes were perceived. This method proved to be very simple and reproducible, since the ruler can be easily pushed into the soft sediment, making it easy to detect the resistance of the rhizomes. (2) We partly removed the sediment above the rhizomes and then measured the sediment depth from the surface to the cleared rhizome again using the ruler. As both methods gave similar results $(F=$ $0.139, p=0.710$ ), in the following experiments, rhi- 
zome depth was determined using method (1). The elongation rate of the rhizomes $\left(\mathrm{cm} \mathrm{d}^{-1}\right)$ was calculated by dividing the length of the newly grown rhizomes by the experimental period. The number of days required to produce a new internode was calculated by dividing the total number of new internodes by the total number of days of the experiment.

\section{Effect of continuous burial and erosion on individual propagules}

To study the effect of continuous erosion or burial on the survival and depth of individual propagules, Zostera noltii propagules were initially planted at depths of $0,0.5$ and $1 \mathrm{~cm}$ for both erosion and burial treatments. The $0 \mathrm{~cm}$ treatment corresponded to a propagule that had experienced an erosion event, so that only the roots were still seated in the sediment. Flume experiments at the NIOO revealed that such units were not washed away by gentle waves or flow, until all the roots were washed out of the sediment (mean root length $\pm \mathrm{SD}=5.11 \pm 1.15 \mathrm{~cm}, \mathrm{n}=672$ ). For the $0.5 \mathrm{~cm}$ and $1.0 \mathrm{~cm}$ treatments, 0.5 or $1.0 \mathrm{~cm}$ from the top of the cylinder was measured and marked using a pencil. Then sediment was filled into the cylinder up to the mark. For the $0 \mathrm{~cm}$ treatment, the cylinder was completely filled with sediment. The roots of individual propagules were carefully placed into the sediment, and the rhizome was located on the sediment surface in all the treatments. Subsequently, for the 0.5 and $1.0 \mathrm{~cm}$ treatments, sediment was carefully placed on top of the rhizome until the cylinder was full. For each treatment, 16 cylinders with 1 propagule each were used.

All plants, independent of planting depth, were exposed to the following burial or erosion treatments: 1 time $0.3 \mathrm{~cm}$ sediment addition or removal in Week 1, 2 times per week $0.3 \mathrm{~cm}$ sediment addition or removal in Weeks $2 \& 3$, and in Week 4 no sediment addition or removal. Thus, at the end of the experiment, a total of $1.5 \mathrm{~cm}$ of sediment was added to or removed from each plant. All plants were grown in PVC cylinders (12 cm in diameter and height) with an open bottom, containing a plastic bag filled with muddy sand. Erosion treatments were applied by placing $0.3 \mathrm{~cm}$ thick discs below the plastic bag, thereby lifting the sediment plus plants, and subsequently carefully removing $0.3 \mathrm{~cm}$ of sediment around the plants, thus mimicking a $0.3 \mathrm{~cm}$ erosion event. Burial treatments were applied by removing $0.3 \mathrm{~cm}$ thick discs from below the plastic bag, which were placed there before planting the seagrass, allowing the bag with sediment plus plants to sink, and carefully adding $0.3 \mathrm{~cm}$ of sediment around the plants. Removal of a disc thus mimicked a $0.3 \mathrm{~cm}$ accretion event. Growing conditions were identical to those in the previously described mesocosm experiment. After $4 \mathrm{wk}$, the number of surviving shoots and surviving plants in each treatment was counted, and the burial depth of each internode between 2 adjacent shoots was measured.

\section{Field experiments}

Effect of burial and uprooting on attached rhizomes at the edge of a meadow

To understand the effect of burial and uprooting on the depth at which Zostera noltii produces new rhizomes at the edge of a meadow, we placed meadowattached apical rhizomes at different depths. At the beginning of the experiment, we measured the natural rhizome burial depth in the field (original depth). Subsequently, we carefully took apical seagrass rhizomes with 3 shoots out of the sediment, tagged the rhizomes with different coloured marks for each treatment, and then placed them back on the sediment surface $(0 \mathrm{~cm}$, as 'erosion treatment'), at the original depth $(\mathrm{N})$ and at 1, 2, 3 or $4 \mathrm{~cm}$ deeper than $\mathrm{N}(\mathrm{n}=8)$. This experiment was carried out on the 'Zandkreek' tidal flat in the eastern Scheldt estuary, SW Netherlands, in August 2009. After 3 wk, the effect of the treatments on the depth of the marked rhizomes was analyzed by determining rhizome depth and counting the number of surviving plants.

\section{Ability of attached rhizomes at the edge of a meadow to invade bare hills and hollows}

To assess the ability of attached rhizomes at the edge of a patch or a meadow to invade bare areas that may be higher (hills) or lower (hollows) than the overall meadow, we created bare areas of different elevation in a Zostera noltii meadow at the 'Slikken van Viane' tidal flat in the eastern Scheldt, SW Netherlands. We randomly applied 56 treatments using a PVC cylinder (diameter $40 \mathrm{~cm}$, height $20 \mathrm{~cm}$ ). At the beginning of the experiment, the cylinder was placed within the meadow, the internode depth of the $Z$. noltii plants inside the cylinder was measured, and all seagrass material above- and belowground was collected to estimate total fresh biomass, showing that there were no biomass differences at the 
beginning of the experiment $(F=1.126, \mathrm{p}=0.361)$ in any of the treatments. In the newly created bare areas, 7 different sediment levels were created relative to the meadow: $+6,+4,+2,0 \mathrm{~cm}$ (control, where sediment was maintained at its original height), -2 , -4 and $-6 \mathrm{~cm}$. For the hill treatments, we filled the cylinder with sediments until accretion reached the selected height (i.e. $+6,+4,+2 \mathrm{~cm}$ ). For the hollow treatments, we washed sediments out of the cylinder until the selected destruction was reached (i.e. -2 , $-4,-6 \mathrm{~cm})$. Each treatment had 8 replicates in a block design.

The experiment started in June 2009 and lasted for 4 wk. Every week, shoot numbers inside each experimental plot were counted. At the end of the experimental period, all seagrass material within the experimental plots was collected and freeze-dried, and the total biomass was weighed. The field experiments were carried out during the calm season of the year and were located at sheltered locations. That is, the sites were specifically selected so that the hydrodynamic forces from tidal currents were insufficient to disturb our experiments by flattening out the hollows and hills. Sediment accretion or erosion rates in the eastern Scheldt are negligible in the short time span used in this experiment (Oenema \& DeLaune 1988). Natural processes, predominantly sediment reworking by burrowing animals and resuspension, slightly altered the sediment levels $(1 \mathrm{~cm}$ elevations or depressions compared to the original at the end of the experiment, except in the $0 \mathrm{~cm}$ treatment) during the course of the experimental period. We chose not to maintain the initial experimental sediment levels, since we intended to mimic the effect of a natural disturbance event.

\section{Statistical analysis}

The effects of burial, erosion and the manipulation of the adjacent sediment height near a seagrass meadow on the elongation rate, survival rate, depth of newly grown rhizomes, fresh and dry biomass and shoot number were analyzed using 1-way ANOVA and post hoc tests. Normality and homogeneity of the data were previously checked, and, when necessary, data were transformed to comply with ANOVA assumptions. Data were presented as means $( \pm \mathrm{SE})$, and a significance level of $5 \%$ was used in all analyses. When ANOVA was significant $(p<0.05)$, the Tukey's multiple comparison test was applied to determine which treatments were significantly different.

\section{RESULTS}

\section{Mesocosm experiments}

\section{Effect of sudden burial on individual propagules}

Survival of Zostera noltii plants was $100 \%$ for individual propagules buried at 0.5 and $1.0 \mathrm{~cm}$, while plant survival decreased when rhizomes were buried deeper than $1 \mathrm{~cm}$ (Fig. 2A). In spite of the observed decline on survival, the rhizome elongation rate of remaining plants was not significantly different among treatments $(F=0.890, \mathrm{p}=0.508)$. It was on average $7.5 \pm 3.7 \mathrm{~mm} \mathrm{~d}^{-1}$, except at $6 \mathrm{~cm}$ burial depth (only 1 seagrass plant was still alive), where the rhizome elongation rate was $2.6 \mathrm{~mm} \mathrm{~d}^{-1}$ (Fig. 2B). The diameter of the rhizome was $1.25 \pm 0.19 \mathrm{~mm}$ and showed no significant differences between treatments. Since the mean shoot length was $5.22 \pm$ $1.16 \mathrm{~cm}(\mathrm{n}=576)$, only at the burial depth of $6 \mathrm{~cm}$ were shoots completely covered by sediment, while half of the shoot was covered at the burial depth of $3 \mathrm{~cm}$. We observed that all newly produced rhizomes of surviving plants had grown towards the sediment surface to a depth ranging from 0.3 to $0.8 \mathrm{~cm}$ (Fig. 2C), which may be regarded as the preferential depth range. When the rhizome was buried at $6 \mathrm{~cm}$, the first new rhizome internode relocated quickly to $2 \mathrm{~cm}$ depth, while the next one was already situated at the preferential depth range (Fig. 2C).

Assuming that plants grew evenly over the experimental period, we assessed that the preferential depth was reached between $2(0.5 \mathrm{~cm}$ treatment $)$ and $16 \mathrm{~d}$ ( $6 \mathrm{~cm}$ treatment). In general, in those plants placed at relatively shallow depths, the first new internode produced had already reached the preferential depth range (Fig. 2C), whereas for the deeper plants the second new internode produced reached the preferential depth range (Fig. 2C). Present results indicated that individual propagules acclimate to moderate sudden burial by rapidly growing upward to the preferential depth range.

\section{Effect of continuous burial and erosion on individual propagules}

Survival of Zostera noltii propagules ranged from 81 to $100 \%$ in all burial and erosion treatments, except for the erosion treatment where additional erosion dislodged some plants from the sediment when initially placed at the sediment surface. The survival of $Z$. noltii was higher under burial than 

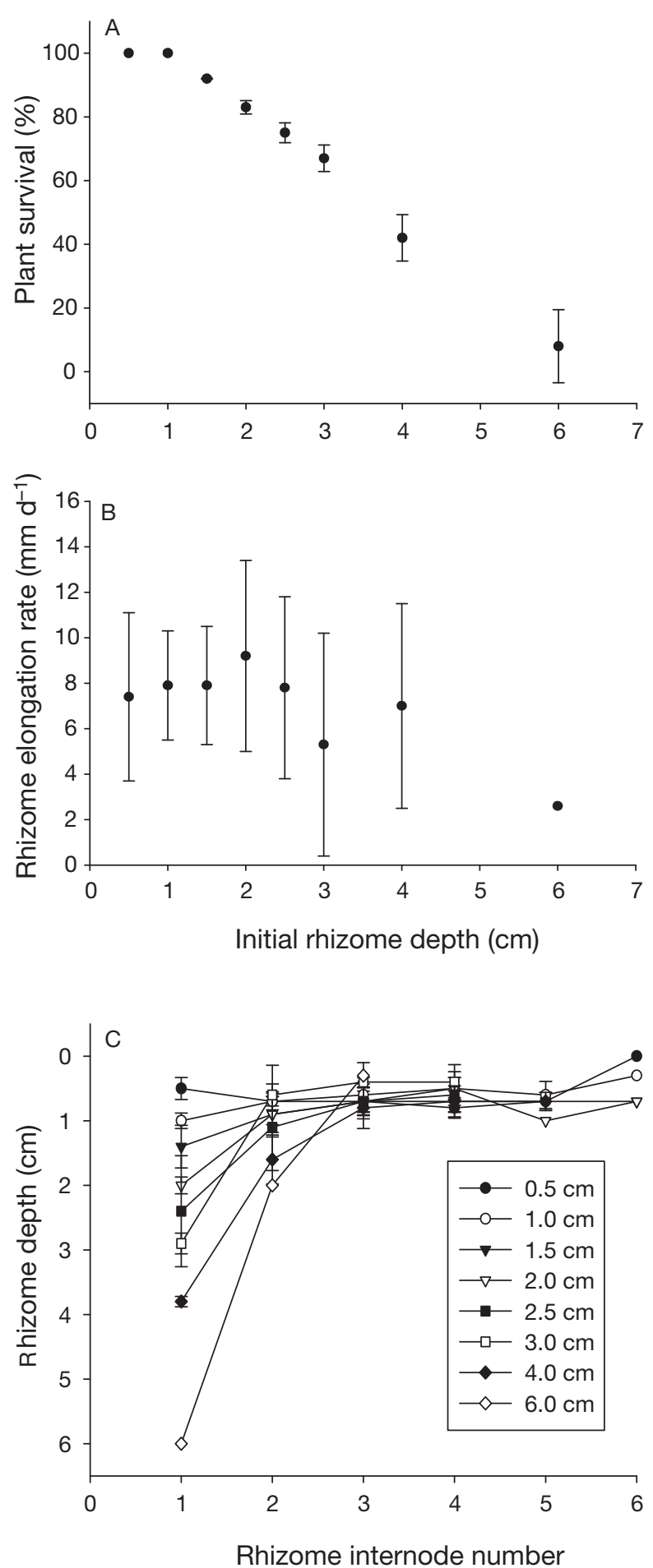

Fig. 2. Zostera noltii. Mesocosm experiment. Effects of different burial depths on (A) plant survival, (B) rhizome elongation rate and $(C)$ rhizome depth of individual propagules after $4 \mathrm{wk}$. In Panel $\mathrm{C}$, the initial burial depths of the individual rhizomes were $0.5,1.0,1.5,2.0,2.5,3.0,4.0$ and $6.0 \mathrm{~cm}$. For rhizome internode codes, the lowest number indicates the oldest internode, the highest number indicates the youngest under comparable erosion treatments (Fig. 3A). The rhizome elongation rate of surviving plants showed no significant difference among treatments and was $8.0 \pm 5.9 \mathrm{~mm} \mathrm{~d}^{-1}(F=0.388, \mathrm{p}=0.855)$. During the first $3 \mathrm{wk}$ that we applied the erosion treatment, the individual rhizomes of $Z$. noltii became uncovered and remained at the sediment surface (i.e. depth $=0 \mathrm{~cm}$ ). Only when the simulated erosion ceased (in the fourth week) were the rhizomes able to grow downwards to a depth ranging from 0.1 to $0.9 \mathrm{~cm}$ (Fig. 3B). The continuous increase in height for the newly formed rhizomes indicated that, throughout the burial treatment, the newly formed rhizomes of $Z$. noltii continuously grew toward a depth of 0.1 to $0.9 \mathrm{~cm}$ (Fig. 3C).

\section{Field experiments}

Effect of burial and uprooting on attached rhizomes at the edge of a meadow

Measurements on a large number of rhizomes in the field $(\mathrm{n}=144)$ indicated that the natural depth of Zostera noltii rhizomes was $0.6 \pm 0.3 \mathrm{~cm}$ (ranging from 0 to $1.4 \mathrm{~cm}$ ). All the plants grew into their preferential depth range during the experimental period. When mimicking uprooting (i.e. when attached rhizomes at the edge of the meadow were placed onto the sediment), the first new internode had already very shallowly grown back into the sediment (Fig. 4A,B). However, it took $21 \mathrm{~d}$ and the production of 4 new rhizomes for the rhizomes to get back to their preferential depth range. When the attached rhizomes at the edge of a meadow were placed at the natural depth, all the new rhizomes produced remained at this depth during the experimental period (Fig. 4A,B). When they were placed 1, 2 and $3 \mathrm{~cm}$ deeper than the natural depth, the second new internode (Fig. 4A) grew to its preferential depth range within circa $10 \mathrm{~d}$, while when they were placed $4 \mathrm{~cm}$ deeper than the natural depth, the third new internode (Fig. 4A,B) grew to the preferential depth range within around $20 \mathrm{~d}$.

\section{Ability of attached rhizomes at the edge of a meadow to invade bare hills and hollows}

The recolonization of a bare area by Zostera noltii was clearly affected by the height of the hills and hollows relative to the surrounding meadow (Fig. 5). Whereas during Week 1 of regrowth, the shoot num- 

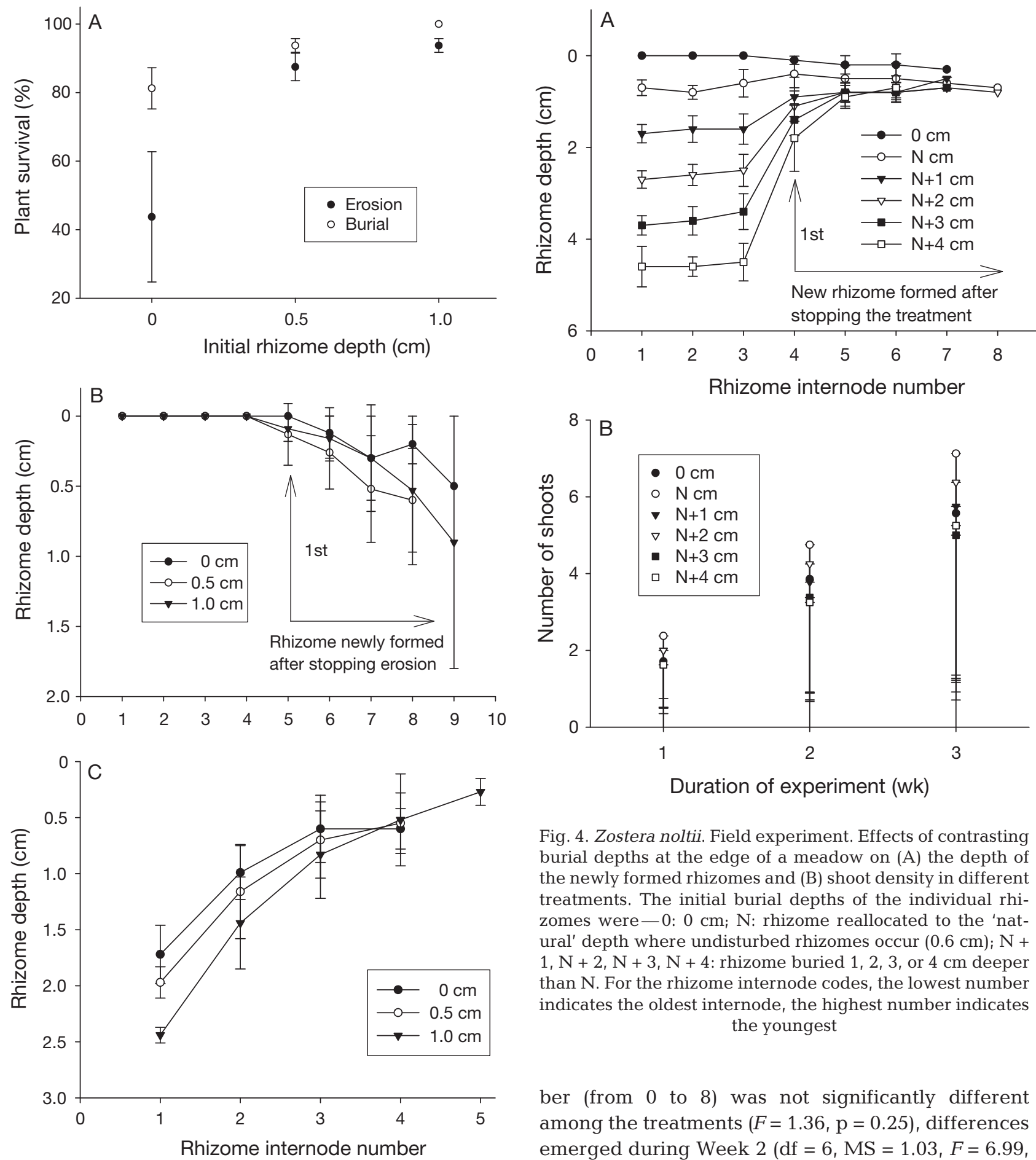

Fig. 4. Zostera noltii. Field experiment. Effects of contrasting burial depths at the edge of a meadow on (A) the depth of the newly formed rhizomes and (B) shoot density in different treatments. The initial burial depths of the individual rhizomes were-0: $0 \mathrm{~cm}$; $\mathrm{N}$ : rhizome reallocated to the 'natural' depth where undisturbed rhizomes occur $(0.6 \mathrm{~cm}) ; \mathrm{N}+$ $1, \mathrm{~N}+2, \mathrm{~N}+3, \mathrm{~N}+4$ : rhizome buried $1,2,3$, or $4 \mathrm{~cm}$ deeper than N. For the rhizome internode codes, the lowest number indicates the oldest internode, the highest number indicates the youngest

ber (from 0 to 8 ) was not significantly different among the treatments $(F=1.36, \mathrm{p}=0.25)$, differences emerged during Week $2(\mathrm{df}=6, \mathrm{MS}=1.03, F=6.99$, $\mathrm{p}<0.05)$ and Week $3(\mathrm{df}=6, \mathrm{MS}=2.13, F=5.32$, $\mathrm{p}<0.05)$. The number of shoots was lower in hills than in hollows in Week $2(t=5.12, \mathrm{p}<0.01)$ and Week $3(t=5.69, \mathrm{p}<0.01$; Fig. 5A). The same pattern was found for total biomass at the end of the experiment $(\mathrm{df}=6, \mathrm{MS}=109, F=8.97, \mathrm{p}<0.01$; Fig. 5B). The total biomass showed the highest values in the hollows with a depth of 2 to $4 \mathrm{~cm}$. tinuous erosion and burial on (A) plant survival, and on the depth of rhizomes at the end of the $4 \mathrm{wk}$ following $3 \mathrm{wk}$ of (B) erosion or (C) burial treatments. For erosion (B) and burial (C) treatments, the initial burial depths were 0, 0.5 and $1.0 \mathrm{~cm}$. For rhizome internode codes, the lowest number indicates the oldest internode, the highest number indicates the youngest

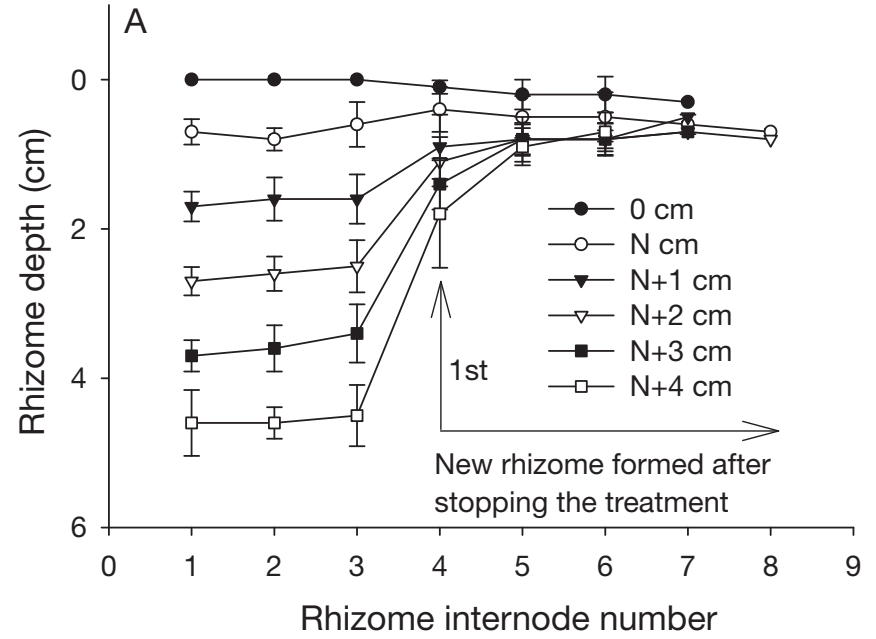



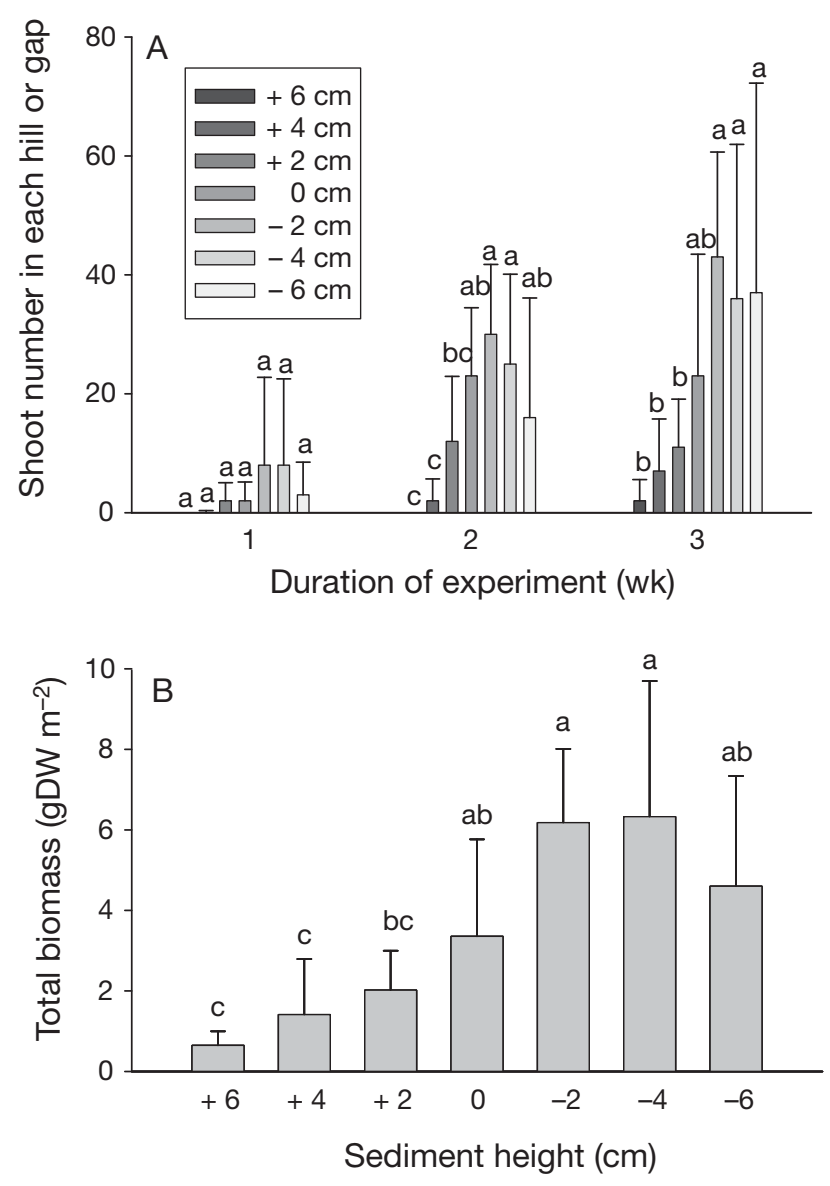

Fig. 5. Zostera noltii. Field experiment. Effects of artificially created hollows and hills at the edge of the meadow on (A) the number of shoots invading the hollows and hills and (B) on the total dry biomass of $Z$. noltii at the end of the experiment. The initial sediment heights were $+6,+4,+2,0,-2,-4$ and $-6 \mathrm{~cm}$ (positive values indicating hill treatments; negative values indicating hollow formation). Bars with different letters were significantly different at the level of $p<0.05$

\section{DISCUSSION}

Many natural and human-induced events create disturbances in seagrasses throughout the world (Orth et al. 2006). Whereas previous studies mainly documented the effect of large-scale homogeneous sediment changes on homogeneous seagrass meadows (reviewed in Cabaço et al. 2008), we studied both individual Zostera noltii propagules and attached $Z$. noltii rhizomes at the edge of a meadow with regards to rapid responses to erosion and sudden and continuous burial. This is the first study to quantify the resilience (acclimation and recovery) of seagrasses to local sediment dynamics and to demonstrate that all surviving plants reestablished their rhizomes at the preferential depth (i.e. the depth at which rhizomes were naturally growing) following erosion and burial disturbances. Such small-scale studies are relevant, as they show recovery through the establishment of new seagrass patches by propagules or by vegetative growth from existing patches. The present study clearly demonstrates that: (1) the intensity and frequency of burial or erosion have different effects on the survival, elongation rate and rhizome depth of Zostera noltii and (2) that $Z$. noltii rapidly acclimates to burial or erosion disturbances by relocating the newly produced rhizomes to a preferential depth (from 0.3 to $0.8 \mathrm{~cm}$ ), both in the mesocosm and field experiments.

Sudden burial caused a linear decrease in survival below the preferential depth (Fig. 2A). For instance, when individual rhizomes were buried at their preferential depth, the survival rate was $100 \%$, while only $6 \%$ survived when individual rhizomes were subjected to $6 \mathrm{~cm}$ of sudden burial (Fig. 2A). This is in line with previous studies showing a decrease in seagrass survival after large-scale sudden burial (see Cymodocea nodosa in Marbà \& Duarte 1994; Posidonia oceanica in Manzanera et al. 1998; Zostera marina in Mills \& Fonseca 2003; and $Z$. noltii in Brun et al. 2005 and Cabaço \& Santos 2007). Increased (sudden) burial depth of individual propagules also caused a strong decrease in the rhizome elongation rate of $Z$. noltii plants (Fig. 2B). Survival of $Z$. noltii plants was much higher under continuous burial (94 to 100\%) compared to the effect of sudden burial. This can be explained because of the higher stress conditions that plants experienced during strong sudden burial (e.g. low light levels and anoxic conditions). The latter might result in a lower capacity to mobilize non-structural carbohydrates to cover metabolic requirements, which negatively affect the plants (Brun et al. 2003). As rapid burial raises the sediment surface, the depth of sediment anoxia almost certainly rises upward toward the photosynthetic portions of the seagrass (Mills \& Fonseca 2003). The latter may result in sulphide intrusion into meristematic areas and buried tissues (Pedersen et al. 2004) and inhibit the plants' recovery from the burial event (Goodman et al. 1995). Survival of plants was consistently higher for the same sediment levels of burial than erosion (Fig. 3A). The high mortality of individual propagules that were initially placed on the sediment surface could be easily explained by plants washed away by hydrodynamic forces (Fig. 3A).

The naturally recorded rhizome depth of Zostera noltii was $0.6 \pm 0.3 \mathrm{~cm}$ (from 0 to $1.4 \mathrm{~cm}$ ) in the field, and the observed preferential depth was 0.3 to $0.8 \mathrm{~cm}$ 
in the mesocosm. This falls within the natural range described for this species (Duarte et al. 1998). In all cases, surviving rhizomes grew rapidly towards an apparently preferential depth range after disturbances. In general, for those plants placed at relatively shallow depths, the first new internode produced can reach the preferential depth range directly (Fig. 2C). In the case of sudden deeper burial, the first new rhizomes produced from surviving rhizomes did not reach the preferential depth range, but the second intenode did (Figs. 2C \& 4A), indicating that $Z$. noltii can rapidly acclimate to moderate sudden burial events. This rapid response may be supported by the apical dominance in $Z$. noltii, suggesting that, under stress conditions, such as sudden burial, plant resources will mainly be directed to the apical shoot (Duarte et al. 1998, Marbà et al. 2002, Brun et al. 2007). Thus, plants buried at deeper points frequently developed rhizomes without shoots when the rhizomes remained well below the preferential depth. The production of new shoots only began again when rhizomes reached the preferential depth, where shoots have access to more favourable light conditions and resume the elongation of vertical internodes until the apical meristem is repositioned at the sediment surface (Terrados 1997, Brun et al. 2005). During erosion events, plants subjected to continuous erosion were unable to bury into the sediment until disturbance ceased (Fig. 3B), and the time needed by plants to reach the preferential depth was directly related to erosion intensity (Fig. 4A,B). The greater the erosion, the longer the period plants remained uncovered and, therefore, the higher the risk of plants being uprooted by waves, currents, or animal activities.

Seagrass patch growth and patterns are affected by external, mainly hydrodynamic factors and the underlying geomorphology of the area (Kendrick et al. 2005). Local sediment disturbances can result in newly created bare gaps and hills within the seagrass landscape (Robbins \& Bell 2000). The recovery of gaps in seagrass meadows has been described for a range of species. Gaps $<25 \mathrm{~m}^{2}$ in Posidonia sinuosa meadows were refilled over $50 \mathrm{yr}$ (Hastings et al. 1995). Thalassia hemprichii grew into experimental $0.25 \mathrm{~m}^{2}$ gaps over $2 \mathrm{yr}$, but Enhalus acoriodes was predicted to take $10 \mathrm{yr}$ to refill these gaps (Rollon et al. 1999). Halodule wrightii beds can fill in small gaps in $<6$ mo (Bell et al. 1999). Our results showed that Zostera noltii can fill in gaps of $0.13 \mathrm{~m}^{2}$ in $1 \mathrm{mo}$. This is much faster than all the above-mentioned seagrasses except for $H$. wrightii. Although our gap was smaller than those observed in previous studies, the rates $\left(0.13 \mathrm{~m}^{2} \mathrm{mo}^{-1}\right)$ clearly indicate that $Z$. noltii can refill the same-size gaps faster than larger seagrass species. This agrees well with the observation that small (pioneer) seagrass species are able to occupy disturbed areas more rapidly than large species (Neckles et al. 2005), as small species have faster rates of horizontal spread than large species (Marbà \& Duarte 1998). Whereas the potential to recover from disturbances by growth is enhanced with decreasing seagrass size, the mortality caused by burial increased with decreasing seagrass size (Duarte et al. 1997, Peralta et al. 2005). Thus, our results show that a trade-off related to seagrass size exists, in terms of recovery time versus resistance to stresses, such as sediment disturbance.

In our field study the growth of Zostera noltii plants into a bare area was clearly affected by relative sediment height compared to the surrounding meadow (Fig. 5). Z. noltii-attached rhizomes at the edge of the meadow can invade hollows more easily than hills. This may be due to the prevention of desiccation provided by the hollows, which facilitates photosynthesis and nutrient uptake during low tide. In contrast, plants on hills may suffer higher desiccation and thereby greatly reduced photosynthetic rates (Leuschner et al. 1998). This response is in agreement with the findings of Rasheed (1999), who found that the size and type of disturbance are likely to influence seagrass recovery. Although seagrass patches can sustain some burial, and patch mortality is more likely to result from erosion (Ramage \& Schiel 1999, Brun et al. 2005), the present study showed that $Z$. noltii patches may recover more rapidly by vegetative growth of the attached rhizomes at the edge of the meadow after moderate erosion (hollows) than after burial (hills) disturbance.

\section{CONCLUSIONS}

The present study showed that Zostera noltii is well adapted to cope with sediment disturbances of limited amplitude (i.e. $\pm 6 \mathrm{~cm}$ ) by rapidly relocating their rhizomes to the preferential depth. This response appears to be quite fundamental to the species, as it was present both in individual propagules and in attached rhizomes at the edges of a meadow. Sudden burial has a much stronger negative effect on the survival response of $Z$. noltii than continuous burial. The effect of erosion differs between individual propagules and attached rhizomes at the edges of a meadow, with individual propagules being more vulnerable due to the risk of being washed away. Our 
study provides a quantitative understanding of the ability of seagrasses like $Z$. noltii to recover from small-scale sediment disturbances, which is important for understanding the mechanisms involved in seagrass degradation and recovery.

Acknowledgements. We thank B. P. Koutstaal, J. van Soelen, L. van IJzerloo, Y. La Nafie, M. Versteeg, Dr. L. Hanssen, J. de Brouwer and L. Govers for their help in the field and in the laboratory. Dr. A. Vonk, Dr. Dongyan Liu and 6 anonymous reviewers are sincerely thanked for stimulating discussions on an earlier version of the manuscript. We also thank the Chinese Academy of Sciences for giving Dr. Qiuying Han the grant to travel to The Netherlands. National science and technology support plan project of China (2010BAC68B01) paid for Open Access of this article.

\section{LITERATURE CITED}

Bell SS, Robbins BD, Jensen SL (1999) Gap dynamics in a seagrass landscape. Ecosystems (N Y) 2:493-504

Bolam SG, Fernandes TF (2002) Dense aggregations of tube-building polychaetes: response to small-scale disturbances. J Exp Mar Biol Ecol 269:197-222

Boström C, Jackson EL, Simenstad CA (2006) Seagrass landscapes and their effects on associated fauna: a review. Estuar Coast Shelf Sci 68:383-403

Brun FG, Hernández I, Bergara JJ, Pérez-Lloréns JL (2003) Growth, carbon allocation and proteolytic activity in the seagrass Zostera noltii shaded by Ulva canopies. Funct Plant Biol 30:551-560

Brun FG, Vergara JJ, Hernández I, Pérez-Lloréns JL (2005) Evidence for vertical growth in Zostera noltii Hornem. Bot Mar 48:446-450

Brun FG, Vergara JJ, Peralta G, García-sánchez MP, Hernández I, Pérez-Lloréns JL (2006) Clonal building, simple growth rules and phylloclimate as key steps to develop functional-structural seagrass models. Mar Ecol Prog Ser 323:133-148

Brun FG, Cummaudo F, Olivé I, Vergara JJ, Pérez-Lloréns JL (2007) Clonal extent, apical dominance and networking features in the phalanx angiosperm Zostera noltii Hornem. Mar Biol 151:1917-1927

> Cabaço S, Santos R (2007) Effects of burial and erosion on the seagrass Zostera noltii. J Exp Mar Biol Ecol 340:204-212

> Cabaço S, Alexandre A, Santos R (2005) Population-level effects of clam harvesting on the seagrass Zostera noltii. Mar Ecol Prog Ser 298:123-129

> Cabaço S, Santos R, Duarte CM (2008) The impact of sediment burial and erosion on seagrasses: a review. Estuar Coast Shelf Sci 79:354-366

> Cruz-Palacios V, van Tussenbroek BI (2005) Simulation of hurricane-like disturbances on a Caribbean seagrass bed. J Exp Mar Biol Ecol 324:44-60

Cunha AH, Santos RP, Gaspar AP, Bairros MF (2005) Seagrass landscape-scale changes in response to disturbance created by the dynamics of barrier-islands: a case study from Ria Formosa (southern Portugal). Estuar Coast Shelf Sci 64:636-644

Dolch T, Reise K (2010) Long-term displacement of intertidal seagrass and mussel beds by expanding large sandy bedforms in the northern Wadden Sea. J Sea Res 63: 93-101

Duarte CM (1995) Submerged aquatic vegetation in relation to different nutrient regimes. Ophelia 41:87-112

Duarte CM, Terrados J, Agawin NSR, Fortes MD, Bach S, Kenworthy WJ (1997) Response of a mixed Philippine seagrass meadow to experimental burial. Mar Ecol Prog Ser 147:285-294

> Duarte CM, Merino M, Agawin NSR, Uri J and others (1998) Root production and belowground seagrass biomass. Mar Ecol Prog Ser 171:97-108

> Goodman JL, Moore KA, Dennison WC (1995) Photosynthetic responses of eelgrass (Zostera marina L.) to light and sediment sulphide in a shallow barrier island lagoon. Aquat Bot 50:37-47

Hammerstrom KK, Kenworthy WJ, Fonseca MS, Whitfield PE (2006) Seed bank, biomass, and productivity of Halophila decipiens, a deep water seagrass on the west Florida continental shelf. Aquat Bot 84:110-120

> Hastings K, Hesp P, Kendrick GA (1995) Seagrass loss associated with boat mooring at Rottnest Island, Western Australia. Ocean Coast Manage 26:225-246

> Hughes RG, Paramor OAL (2004) On the loss of saltmarshes in south-east England and methods for their restoration. J Appl Ecol 41:440-448

Kendrick GA, Duarte CM, Marbà N (2005) Clonality in seagrasses, emergent properties and seagrass landscapes. Mar Ecol Prog Ser 290:291-296

Leuschner C, Landwehr S, Mehlig U (1998) Limitation of carbon assimilation of intertidal Zostera noltii and Z. marina by desiccation at low tide. Aquat Bot 62: 171-176

> Manzanera M, Pérez M, Romero J (1998) Seagrass mortality due to oversedimentation: an experimental approach. J Coast Conserv 4:67-70

- Marbà N, Duarte CM (1994) Growth response of the seagrass Cymodocea nodosa to experimental burial and erosion. Mar Ecol Prog Ser 107:307-311

Marbà N, Duarte CM (1998) Rhizome elongation and seagrass clonal growth. Mar Ecol Prog Ser 174:269-280

- Marbà N, Hemminga MA, Mateo MA, Duarte CM, Mass YEM, Terrados J, Gacia E (2002) Carbon and nitrogen translocation between seagrass ramets. Mar Ecol Prog Ser 226:287-300

> Mills KE, Fonseca MS (2003) Mortality and productivity of eelgrass Zostera marina under conditions of experimental burial with two sediment types. Mar Ecol Prog Ser 255:127-134

Neckles HA, Short FT, Barker S, Kopp BS (2005) Disturbance of eelgrass Zostera marina by commercial mussel Mytilus edulis harvesting in Maine: dragging impacts and habitat recovery. Mar Ecol Prog Ser 285:57-73

$>$ Oenema O, DeLaune RD (1988) Accretion rates in salt marshes in the eastern Scheldt, south-west Netherlands. Estuar Coast Shelf Sci 26:379-394

> Olesen B, Marbà N, Duarte CM, Sabela RS, Fortes MD (2004) Recolonization dynamics in a mixed seagrass meadow: the role of clonal versus sexual processes. Estuaries 27:770-780

> Orth RJ, Carruthers TJB, Dennison WC, Duarte CM and others (2006) A global crisis for seagrass ecosystems. Bioscience 56:987-996

$>$ Pedersen O, Binzer T, Borum J (2004) Sulphide intrusion in eelgrass (Zostera marina L.). Plant Cell Environ 27: 595-602 
Peralta G, Pérez-Lloréns JL, Hernández I, Vergara JJ (2002) Effects of light availability on growth, architecture and nutrient content of the seagrass Zostera noltii Hornem. J Exp Mar Biol Ecol 269:9-26

Peralta G, Brun FG, Hernández I, Vergara JJ, Pérez-Lloréns JL (2005) Morphometric variations as acclimation mechanisms in Zostera noltii beds. Estuar Coast Shelf Sci 64:347-356

Polte P, Schanz A, Asmus H (2005) Effects of current exposure on habitat preference of mobile 0-group epibenthos for intertidal seagrass beds (Zostera noltii) in the northern Wadden Sea. Estuar Coast Shelf Sci 62:627-635

Preen AR, Long WJL, Coles RG (1995) Flood and cyclone related loss, and partial recovery, of more than $1000 \mathrm{~km}^{2}$ of seagrass in Hervey Bay, Queensland, Australia. Aquat Bot 52:3-17

Ramage DL, Schiel DR (1999) Patch dynamics and response to disturbance of the seagrass Zostera novazelandica on intertidal platforms in southern New Zealand. Mar Ecol Prog Ser 189:275-288

Rasheed MA (1999) Recovery of experimentally created gaps within a tropical Zostera capricorni (Aschers.) seagrass meadow, Queensland Australia. J Exp Mar Biol Ecol 235:183-200

Robbins BD, Bell SS (2000) Dynamics of a subtidal seagrass landscape: seasonal and annual change in relation to water depth. Ecology 81:1193-1205

Rollon RN, van Steveninck ED, van Vierssen W, Fortes MD (1999) Contrasting recolonization strategies in multispecies seagrass meadows. Mar Pollut Bull 37:450-459

Editorial responsibility: Just Cebrian,

Dauphin Island, Alabama, USA
Schanz A, Asmus H (2003) Impact of hydrodynamics on development and morphology of intertidal seagrasses in the Wadden Sea. Mar Ecol Prog Ser 261:123-134

> Short FT, Neckles HA (1999) The effects of global climate change on seagrasses. Aquat Bot 63:169-196

Short FT, Wyllie-Echeverria S (1996) Natural and humaninduced disturbance of seagrasses. Environ Conserv 23: $17-27$

Terrados J (1997) Is light involved in the vertical growth response of seagrasses when buried by sand? Mar Ecol Prog Ser 152:295-299

- Terrados J, Duarte CM, Fortes MS, Borum J and others (1998) Changes in community structure and biomass of seagrass communities along gradients of siltation in SE Asia. Estuar Coast Shelf Sci 46:757-768

van Katwijk MM, Hermus DCR, de Jong DJ, Asmus RM, de Jonge VN (2000) Habitat suitability of the Wadden Sea for restoration of Zostera marina beds. Helgol Mar Res 54:117-128

> Vonk JA, Kneer D, Stapel J, Asmus H (2008) Shrimp burrow in tropical seagrass meadows: an important sink for litter. Estuar Coast Shelf Sci 79:79-85

Waycott M, Duarte CM, Carruthers TJB, Orth RJ and others (2009) Accelerating loss of seagrasses across the globe threatens coastal ecosystems. Proc Natl Acad Sci USA 106:12377-12381

> Zipperle AM, Coyer JA, Reise K, Stam WT, Olsen JL (2009) Evidence for persistent seed banks in dwarf eelgrass Zostera noltii in the German Wadden Sea. Mar Ecol Prog Ser 380:73-80

Submitted: April 11, 2011; Accepted: November 27, 2011 Proofs received from author(s): February 21, 2012 